\title{
Tyrosine phosphatase and cytochrome P450 activity are critical in regulating store-operated calcium channels in human fibroblasts
}

\author{
Kyung-Mi Lee ${ }^{1,4 *}$, Sang-Wook Son ${ }^{2 *}$, \\ György Babnigg ${ }^{3}$ and Mitchel L. Villereal ${ }^{3,4}$
}

\author{
${ }^{1}$ Department of Biochemistry and \\ Division of Brain Korea 21 Program for Biomedical Science \\ ${ }^{2}$ Deaprtment of Dermatology \\ Korea University College of Medicine \\ Seoul 136-705, Korea \\ ${ }^{3}$ Department of Neurobiology \\ University of Chicago \\ Chicago, Illinois 60637, USA \\ ${ }^{4}$ Corresponding authors: Tel, 82-2-920-6409 (KML); \\ 1-773-702-9334 (MLV); \\ Fax, 82-2-928-4853 (KML); 1-773-702-9334 (MLV); \\ E-mail, kyunglee@korea.ac.kr (KML); \\ mitch@drugs.bsd.uchicago.edu (MLV) \\ *These authors contributed equally to this work.
}

\section{Accepted 18 November 2006}

Abbreviations: BAPTA-AM, bis-(O-aminophenoxy)ethane-N,N,N',N'tetraacetic acid, tetra-acetoxymethyl ester; BK, Lys-bradykinin; $\left[\mathrm{Ca}^{2+}\right]$, intracellular free calcium concentration; EET, epoxyeicosatrienoic acids; HSWP, human foreskin fibroblast cells; Ins $(1,3,4,5) \mathrm{P}_{4}$, inositol 1,3,4,5-tetrakisphosphates; $\operatorname{Ins}(1,4,5) \mathrm{P}_{3}$, inositol 1,4,5-trisphosphates; PI, phosphatidylinositol; $\mathrm{PIP}_{2}$, phosphatidylinositol 4,5-bisphosphates

\begin{abstract}
Diverse signaling pathways have been proposed to regulate store-operated calcium entry (SOCE) in a wide variety of cell types. However, it still needs to be determined if all of these known pathways operate in a single cell type. In this study, we examined involvement of various signaling molecules in SOCE using human fibroblast cells (HSWP). Bradykinin (BK)-stimulated $\mathrm{Ca}^{2+}$ entry, previously shown to be via SOCE, is enhanced by the addition of vanadate, an inhibitor of tyrosine phosphatases. Furthermore, SOCE is regulated by cytochrome P-450, as demonstrated by the fact that the products of cytochrome P-450 activity (14,15 EET) stimulated SOCE while econazole, an inhibitor of cytochrome P450, suppressed BK-stimulated $\mathrm{Ca}^{2+}$ entry. In
\end{abstract}

contrast, $\mathrm{Ca}^{2+}$ entry was unaffected by the guanylate cyclase inhibitor LY83583, or the membrane permeant cyclic GMP analog 8-bromo-cyclic GMP (8-Br-cGMP). Neither nitric oxide donors nor phorbol esters affected BK-stimulated $\mathrm{Ca}^{2+}$ entry. SOCE in HSWP cells is primarily regulated by tyrosine phosphorylation and the cytochrome P-450 pathway, but not by cyclic GMP, nitric oxide, or protein kinase C. Thus, multiple pathways do operate in a single cell type leading to the activation of $\mathrm{Ca}^{2+}$ entry and some of these signaling pathways are more prominently involved in regulating calcium entry in different cell types.

Keywords: bradykinin; calcium channels; protein-tyrosine kinases; protein-tyrosine phosphatases

\section{Introduction}

One of the early events following stimulation of many $G$ protein coupled receptors is an increase in the intracellular $\mathrm{Ca}^{2+}$ concentration $\left(\left[\mathrm{Ca}^{2+}\right]_{\mathrm{i}}\right.$ ) (Bird et al., 2004), which initiates a cascade of signal transduction events often leading to DNA synthesis and cell proliferation (Parekh and Putney, 2005). Typically, the $\mathrm{Ca}^{2+}$ response evoked by agonists is a biphasic one that includes a peak and a sustained plateau. The peak is due to the release of intracellular $\mathrm{Ca}^{2+}$ from Ins $(1,4,5) \mathrm{P}_{3}$-sensitive internal stores and the sustained plateau is due to $\mathrm{Ca}^{2+}$ entry from the extracellular space. The relationship between the release of internal $\mathrm{Ca}^{2+}$ stores and activation of $\mathrm{Ca}^{2+}$ entry has been examined in depth and the prevailing hypothesis is that the two events are functionally coupled. Jim Putney first defined "capacitative calcium entry", also called "store-operated calcium entry (SOCE)", as $\mathrm{Ca}^{2+}$ entry initiated by a signal generated when $\mathrm{Ca}^{2+}$ stores are emptied (Putney and McKay, 1999). But what is the signal that is produced by a decrease in the $\mathrm{Ca}^{2+}$ loading state of the internal store that, in turn, communicates with $\mathrm{Ca}^{2+}$ channels in the plasma membrane? A direct interaction between store-operated channels and $\mathrm{IP}_{3}$ receptors, the insertion of sub-membrane vesicles containing store-operated channels into the plasma membrane, or a secretion-like coupling may be involved in regulation of SOCE (Parekh and Putney, 
$2005 \mathrm{~b})$. One can not ignore the wealth of evidence arguing for the involvement of various signal transduction pathways in the regulation of SOCE.

Irvine proposed a model that suggested the involvement of $\operatorname{Ins}(1,4,5) \mathrm{P}_{3}$ and $\operatorname{Ins}(1,3,4,5) \mathrm{P}_{4}$ receptors in activating $\mathrm{Ca}^{2+}$ entry following depletion of $\mathrm{Ca}^{2+}$ stores (1991). In addition to inositol phosphates, several other signaling molecules have been reported to play a role in $\mathrm{Ca}^{2+}$ entry following internal $\mathrm{Ca}^{2+}$ store depletion. Cyclic GMP has been implicated in the regulation of SOCE in pancreatic acinar cells (Bahnson et al., 1993), in vascular endothelial cells (Kwan et al., 2000) and platelets (Rosado et al., 2001). A role for cytochrome P450 enzymes has been suggested for the regulation of SOCE in thymocytes (Alvarez et al., 1991), platelets (Alonso et al., 1991), and human neutrophils (Montero et al., 1991). In addition, small molecular weight $G$ proteins have been shown to regulate SOCE in mouse lacrimal acinar cells (Bird and Putney, 1993) and HL-60 granulocytes (Jaconi et al., 1993). In Jurkat $\mathrm{T}$ cells, a small molecule named $\mathrm{Ca}^{2+}$-influx factor (CIF), generated during stimulation of cells, was reported to activate $\mathrm{Ca}^{2+}$ influx in several cell lines (Randriamampita and Tsien, 1993). The nitric oxide pathway (Favre et al., 1998) and epoxyecosatrienoic acids (EETs) (Graier et al., 1995; Rzigalinski et al., 1999) also have been suggested for regulation of SOCE.

In addition to the pathways described above, we have provided evidence for the role of tyrosine kinases in the regulation of SOCE in human fibroblast cells (Lee et al., 1993). A number of subsequent reports have supported our findings that tyrosine kinases are involved in regulating SOCE in many cell types (Marhaba et al., 1996; Davis and Sharma, 1997; Krutetskaia et al., 1997; Taketo et al., 1997). In addition, studies of platelets indicate that depletion of $\mathrm{Ca}^{2+}$ from intracellular stores leads to the tyrosine phosphorylation of a $130 \mathrm{kD}$ protein, which led to speculation that this protein is involved in the regulation of $\mathrm{Ca}^{2+}$ entry (Vostal et al., 1991).

Since the studies defining the role of these numerous signaling pathways in regulating SOCE involve a wide range of cell types, the question arises whether the evidence for multiple signaling pathways simply reflects variations in the method of regulation between different cell and tissue types, or whether these multiple signaling pathways are all involved in regulating SOCE in a single cell type. That is, do all of these signaling pathways converge on SOCs in most cell types or are there differences between cell types in how they regulate SOCE? To answer this question, we have stimulated human fibroblast (HSWP) cells with bradykinin or thapsigargin, both agents capable of inducing SOCE (Lee et al., 1993) and examined the role of various signaling pathways. Our results indicate that $\mathrm{Ca}^{2+}$ entry into HSWP cells is dynamically regulated by tyrosine kinases and phosphatases and is independent of cyclic GMP, nitric oxide, and diacyIglycerol acting via a classic PKC pathway.

\section{Materials and Methods}

\section{Cell culture}

Human foreskin fibroblast cells (HSWP) were obtained from J. Regan, Oak Ridge National Laboratory. Cells between the 15th and 25th passage were plated in $100 \mathrm{~mm}$ dishes in Eagle's minimal essential medium (EMEM) containing $10 \%$ fetal bovine serum. DDT1MF-2 cells were provided by Donald Gill, University of Maryland School of Medicine, and were grown in DMEM $+10 \%$ FBS. Cells were grown at $37^{\circ} \mathrm{C}$ in a humidified atmosphere containing $5 \% \mathrm{CO}_{2}$ and $95 \%$ air. For single cell image analysis, cells were subcultured on 25 $\mathrm{mm}$ round glass coverslips.

\section{Immunoblotting of whole cell lysates with monoclonal anti-phosphotyrosine antibodies}

HSWP cells were serum deprived in EMEM for $6 \mathrm{~h}$ at $37^{\circ} \mathrm{C}$. Following stimulation, cells were washed with isotonic ice-cold Tris buffered saline (TBS, 10 $\mathrm{mM}$ Tris, $75 \mathrm{mM} \mathrm{NaCl}, 75 \mathrm{mM} \mathrm{KCl}, \mathrm{pH}$ 7.4) and extracted in isoelectrofocusing stop solution (IEF, 8M urea, $0.5 \%$ SDS, $50 \mathrm{mM}$ 2-mercaptoethanol). A fraction $(10 \mu \mathrm{g}$ of protein) of each sample was solubilized by boiling in an equal volume of $2 \times$ Laemmli buffer (62 mM Tris, $1 \%$ SDS, $0.001 \%$ pyronin $Y, 10 \%$ glycerol, 5\% 2-mercaptoethanol) and separated by SDS-PAGE on $7.5 \%$ polyacrylamide minigel. Proteins were transferred to nitrocellulose membranes and nonspecific binding sites were blocked by incubating the membranes in blocking buffer $(150 \mathrm{mM} \mathrm{NaCl}, 10 \mathrm{mM}$ sodium phosphates, $\mathrm{pH} 7.4,2 \mathrm{mM}$ EDTA, $0.2 \%$ NP-40) containing 5 $\mathrm{mg} / \mathrm{ml}$ of BSA for $2 \mathrm{~h}$ at room temperature. Monoclonal anti-phosphotyrosine antibodies at a concentration of $0.5 \mu \mathrm{g} / \mathrm{ml}$ were added to the blot and incubated overnight at $4^{\circ} \mathrm{C}$. The blot was washed 5 times with blocking buffer. Then, anti-mouse IgG $\mathrm{F}(\mathrm{ab})_{2}$ conjugated to horseradish peroxidase $(2 \mu \mathrm{g}$ $/ \mathrm{ml}$ in blocking buffer) was added to the blot and incubated for $1 \mathrm{~h}$ at room temperature. The blot was washed 5 times and subjected to enhanced chemiluminescence $(E C L)$. 


\section{Measurements of $\left[\mathrm{Ca}^{2+}\right]_{i}$ by image analysis}

Image analysis was carried out as previously described (Byron and Villereal, 1989; Lee et al., 1993). All image analysis was conducted at room temperature. Coverslips were washed twice with control medium (135 mM NaCl, $5 \mathrm{mM} \mathrm{KCl,} 1 \mathrm{mM}$ $\mathrm{CaCl}_{2}, 1 \mathrm{mM} \mathrm{MgCl}$, $11 \mathrm{mM}$ glucose, $11 \mathrm{mM}$ Hepes, $\mathrm{pH}$ 7.4) and then incubated in the same medium with $2 \mu \mathrm{M}$ fura-2 $\mathrm{AM}, 0.5 \%$ bovine serum albumin and $0.02 \%$ Pluronic F127 detergent (Poenie et al. 1986) for 90-120 min at room temperature in the dark. After loading, the cells were washed twice and incubated in the dark in control medium for $1-2 \mathrm{~h}$ prior to the image analysis. Fura-2 fluorescence was then measured in cell populations with a Perkin-Elmer LS50B fluorescence spectrophotometer. This instrument was equipped with a rotating filter wheel that was used to alternate between 340 and $380 \mathrm{~nm}$ excitation, and the emitted fluorescence (at $510 \mathrm{~nm}$ ) was determined. A coverslip was mounted vertically at a 30 deg angle to the light path in a cuvette that was continuously perfused with media. A four-way valve mounted just above the cuvette allowed rapid switching of solutions. Replacement of the medium bathing the cells took approximately $10 \mathrm{~s}$. The excitation light illuminated an area of approximately $30 \mathrm{~mm}^{2}$ on the coverslip for recording of fluorescence from several thousand cells. The ratio of fluorescence at $340 \mathrm{~nm}$ to that at $380 \mathrm{~nm}$ was calculated and calibrated in terms of $\left[\mathrm{Ca}^{2+}\right]_{\text {. }}$.

\section{Materials}

Fura-2 free acid, Fura-2 AM, and BAPTA-AM were purchased from Molecular Probes. Lys-Bradykinin and EGF were purchased from Peninsula Laboratories. Monoclonal anti-phosphotyrosine antibodies were purchased from UBI. Peroxidase conjugated anti-mouse $\lg G \mathrm{~F}\left(\mathrm{ab}^{\prime}\right)_{2}$ and $\mathrm{ECL}$ kits were purchased from Amersham. Econazole, 8-bromo cyclic GMP, and sodium orthovanadate were purchased from Sigma. LY83583 was purchased from Calbiochem. 14,15 EET was synthesized by Dr. J.R. Falck (University of Texas Southwestern Medical Center, Dallas, TX). GEA3162 was purchased from Alexis Corp (San Diego, CA).

\section{Statistics}

Results are expressed as means \pm S.E. Where appropriate, results were compared using Student's $t$-test.

\section{Results}

\section{Vanadate enhanced tyrosine phosphorylation and $\mathrm{Ca}^{2+}$ entry stimulated by $\mathrm{BK}$}

We showed previously that the amount of SOCE stimulated by either BK or thapsigargin is decreased by tyrosine kinase inhibitors (Lee et al., 1993). Since the level of tyrosine phosphorylation is determined by the activity of tyrosine kinases and tyrosine phosphatases, we investigated whether modulation of cellular tyrosine phosphatase activity affects the $\mathrm{Ca}^{2+}$ entry induced by $\mathrm{BK}$, as well as the level of tyrosine phosphorylation. Figure 1 shows the time course for protein tyrosine phosphorylation following stimulation of HSWP cells with BK, as analyzed by Western blots with anti-phosphotyrosine antibodies. BK-induced protein tyrosine phosphorylation peaked at $2 \mathrm{~min}$ and gradually declined in $10 \mathrm{~min}$ to a level that was still substantially higher than that of the unstimulated control. Two abundant substrates for BK-stimulated tyrosine phosphorylation are proteins of approximately $130 \mathrm{kDa}$ and $70 \mathrm{kDa}$ (Figure 1). In addition to these proteins, minor proteins in the 205-220 kDa, $190 \mathrm{kDa}, 100-110 \mathrm{kDa}$, and $80 \mathrm{kDa}$ ranges, which also undergo tyrosine phosphorylation by $\mathrm{BK}$, were detected upon longer exposure of the blots. The increase in tyrosine phosphorylation could be the result of stimulation of tyrosine kinase activity and/or inhibition of tyrosine phosphatase activity.

Figure $2 \mathrm{~A}$ shows the effect of vanadate, a well known inhibitor of protein tyrosine phosphatases (Swarup et al., 1982), on basal or BK-stimulated tyrosine phosphorylation. Incubation of cells with $200 \mu \mathrm{M}$ vanadate resulted in elevation of phosphotyrosine levels in both the $130 \mathrm{kDa}$ and $70 \mathrm{kDa}$ proteins. The onset of action for vanadate was very fast, since elevation of tyrosine phosphorylation was detected within 1 min of incubation (Figure $2 \mathrm{~A}$, lane 2). BK further increased the phosphotyrosine levels of the 130 and $70 \mathrm{kDa}$ proteins in cells preincubated

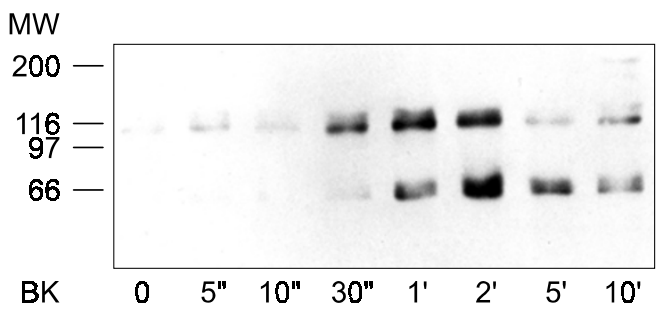

Figure 1. BK stimulates tyrosine phosphorylation in a time-dependent manner. HSWP cells were stimulated with $100 \mathrm{ng} / \mathrm{ml}$ of BK for the indicated time and analyzed for tyrosine-phosphorylated proteins by immunoblotting as described under Materials and Methods. " and ' represent seconds and min, respectively. The results shown are representative of 5 different experiments. 
A

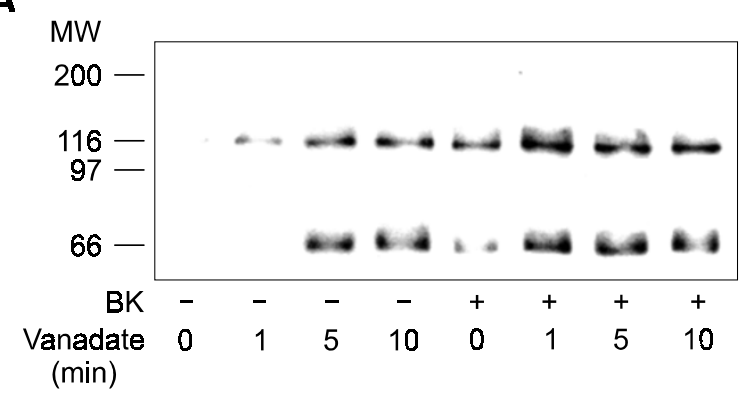

B

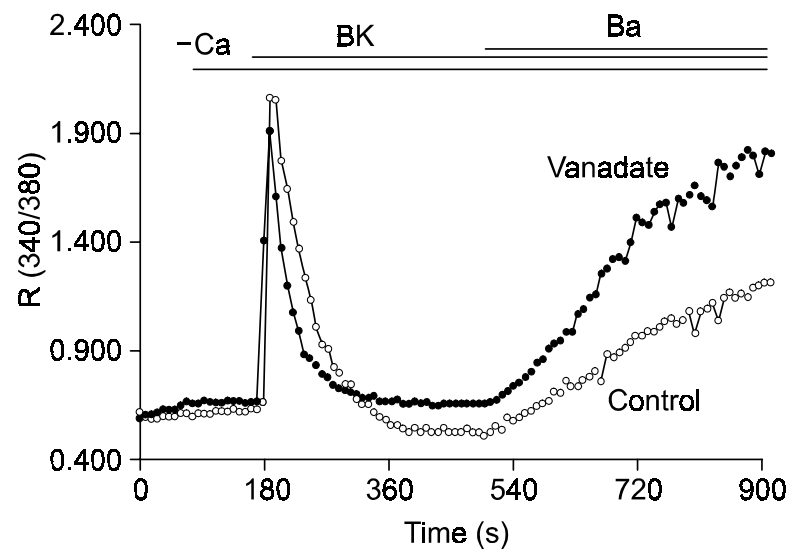

Figure 2. Effects of vanadate on tyrosine phosphoryaltion and $\mathrm{Ba}^{2+}$ influx induced by BK. (A) Cells were incubated with $200 \mu \mathrm{M}$ vanadate (lane 1-4) for the time indicated. In lanes 5-8, cells were preincubated with $200 \mu \mathrm{M}$ vanadate for the time indicated and stimulated with BK for $1 \mathrm{~min}$. Subsequently tyrosine-phosphorylated proteins were analyzed by immunoblotting as described under Materials and Methods. The data shown represents the results from two identical experiments. (B) Each trace is from an individual cell in a field of cells and represents the typical response. Cells were perfused with Hepes-HBSS and then switched to the medium shown at the time indicated by the bar. For the vanadate-treated cells, $200 \mu \mathrm{M}$ vanadate was included during the time BK was present. The concentration for BK was $100 \mathrm{ng} / \mathrm{ml}$. The rate of $\mathrm{Ba}^{2+}$ entry, calculated from the slope of $\mathrm{Ba}^{2+}$-containing phase, was $15.5 \pm 7.5 \times 10^{-4}$ (mean \pm S.E.; $n=17$ ) in the control and $26.4 \pm$ $4.6 \times 10^{-4}$ (mean \pm S.E.; $n=19$ ) in the group treated with vanadate. These values were statistically different $(P<0.0001)$.

with vanadate (Figure $2 \mathrm{~A}$, lane 6-8). The additive effect of vanadate and BK on tyrosine phosphorylation supports our previous findings that BKstimulated tyrosine phosphorylation is mediated by activation of tyrosine kinases rather than by modulation of tyrosine phosphatases. Tyrosine phosphorylation of the $130 \mathrm{kDa}$ range proteins was detected prior to that of the $70 \mathrm{kDa}$ range proteins in cells stimulated by vanadate (Figure $2 \mathrm{~A}$, lane 2 ).

Since vanadate enhances tyrosine phosphorylation in BK-stimulated cells, we next examined whether an additive effect of vanadate can also be observed on BK-stimulated $\mathrm{Ca}^{2+}$ entry. For this purpose, we performed image analysis to monitor intracellular $\mathrm{Ca}^{2+}$ concentration in individual HSWP cells using fura-2. In order to look at $\mathrm{Ca}^{2+}$ influx pathways more closely, we applied a protocol that has been described previously (Lee et al., 1993). Specifically, cells were stimulated with BK in the absence of extracellular $\mathrm{Ca}^{2+}$, so that the BKsensitive internal $\mathrm{Ca}^{2+}$ stores were depleted. Subsequently, $\mathrm{Ba}^{2+}\left(2 \mathrm{mM} \mathrm{BaCl}_{2}\right)$ was added to the medium and the rate of $\mathrm{Ba}^{2+}$ entry was monitored. Since $\mathrm{Ba}^{2+}$ can enter the cell as $\mathrm{Ca}^{2+}$ does, but cannot be pumped out of the cell or into the internal $\mathrm{Ca}^{2+}$ stores, $\mathrm{Ba}^{2+}$ is trapped in the cytoplasm (Schilling et al., 1989). Therefore, increases in $\mathrm{Ba}^{2+}$ concentration in the cells reflect $\mathrm{Ba}^{2+}$ influx across the plasma membrane, which is indicative of activation of $\mathrm{Ca}^{2+}$ entry pathways. Since $\mathrm{Ba}^{2+}$ shifts the $\mathrm{Ca}^{2+}$ calibration of fura-2 (Schilling et al., 1989), the data are presented as a ratio of the 340 and 380 $\mathrm{nm}$ signals, designated as R (340/380). Similar to the effects of vanadate on BK-stimulated tyrosine phosphorylation, vanadate caused enhancement of $\mathrm{BK}^{-s t i m u l a t e d ~} \mathrm{Ba}^{2+}$ influx [Figure 2B, $15.5 \pm 1.81 \times$ $10^{-4}$ (mean \pm S.E.; $n=17$ ) in the control and $26.4 \pm$ $1.05 \times 10^{-4}$ (mean \pm S.E.; $\left.n=19\right)$ in the vanadatetreated group]. The rate of $\mathrm{Ba}^{2+}$ entry in the vanadate-treated group was statistically different from that observed in the control group $(P<0.001)$. Vanadate treatment did not change the level of the $\mathrm{Ca}^{2+}$ peak, suggesting that the $\mathrm{Ca}^{2+}$ release caused by BK was not significantly affected by vanadate. These results indicate that SOCE caused by BK stimulation is regulated by vanadate and this effect correlates with the inhibitory action of vanadate on the tyrosine phosphatase activity.

\section{Role of cyclic GMP in the BK-stimulation of $\mathrm{Ca}^{2+}$ entry and protein tyrosine phosphorylation}

Previous observations in pancreatic acinar cells and platelets suggest that cyclic GMP can regulate SOCE. Since BK has been shown to activate guanylate cyclase and generate cyclic GMP (Snider and Richelson, 1984), we examined the possibility of cyclic GMP being a modulator of SOCE in HSWP cells. To address this question, we first examined the effect of LY83583, an inhibitor of guanylate cyclase (Mulsch et al., 1988), on the $\mathrm{Ca}^{2+}$ response stimulated by BK. In contrast to reports concerning pancreatic acinar cells, neither the acute addition of LY83583 nor preincubation for $10 \mathrm{~min}$ prior to BK stimulation had any effect on the intracellular $\mathrm{Ca}^{2+}$ responses produced by $\mathrm{BK}$ (Figure $3 \mathrm{~A}$ and $\mathrm{B}$ ). These results were further verified by application of 

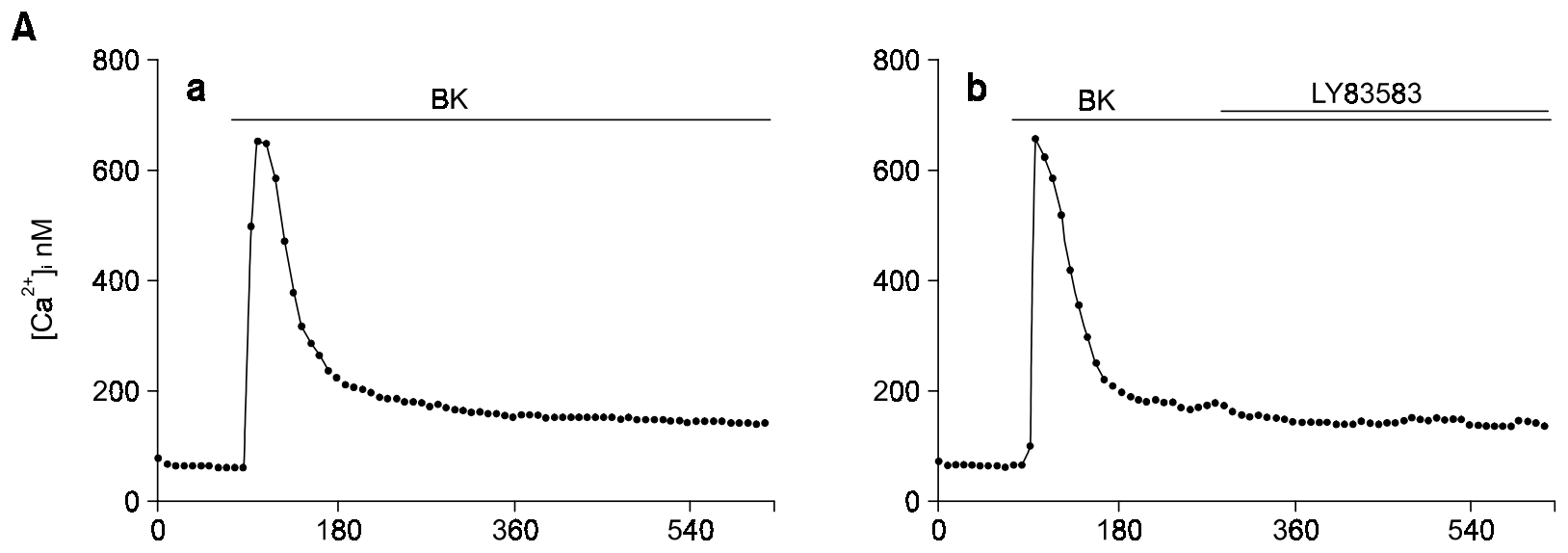

B
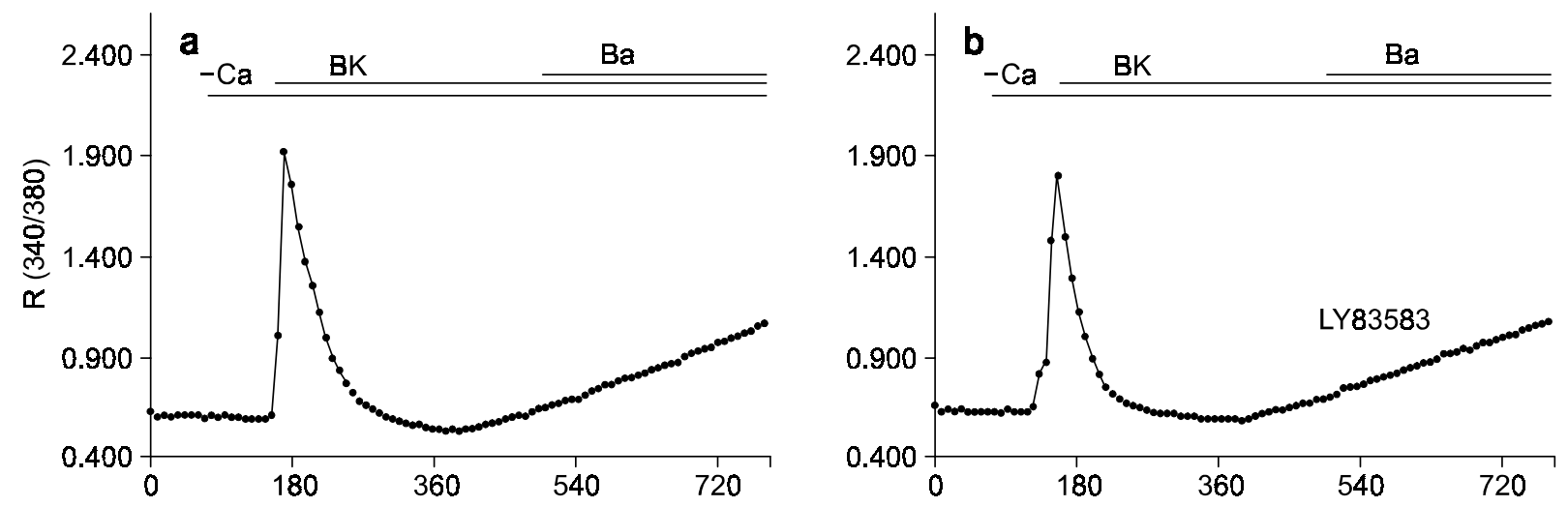

C
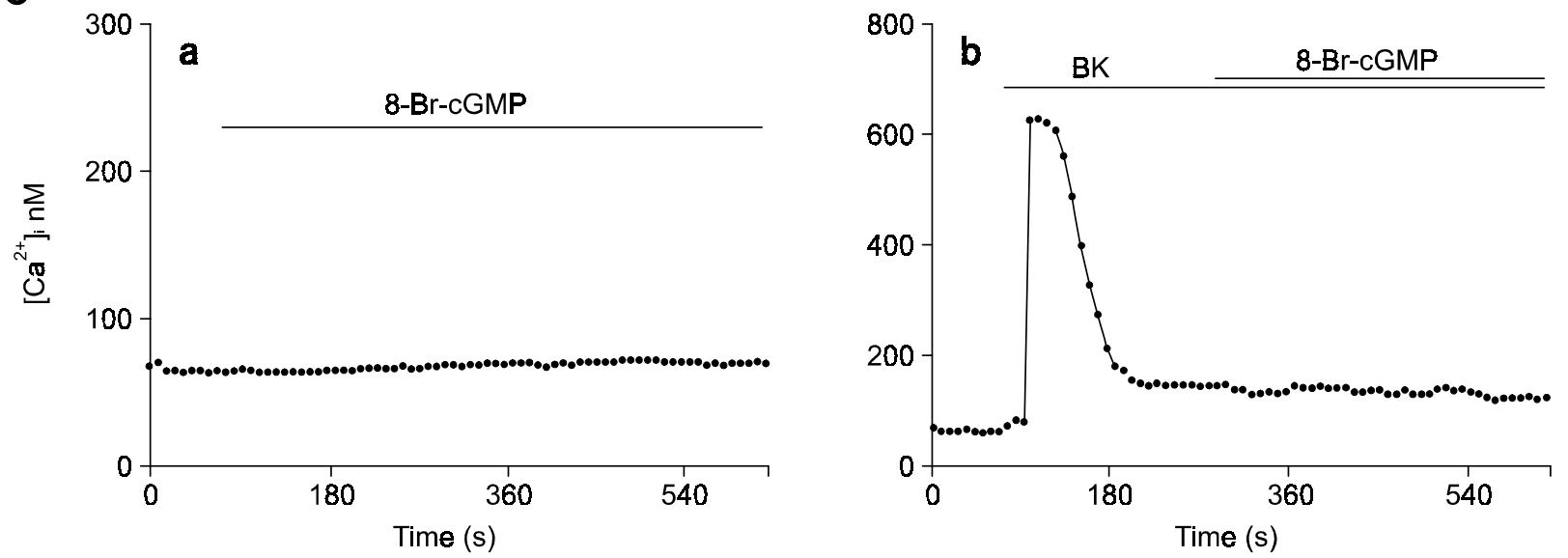

Figure 3. Effects of LY83583 and 8-Br-cGMP on the BK-stimulated $\mathrm{Ca}^{2+}$ entry. Each trace shown is from an individual cell in a field of cells and represents a typical response of 45 cells from 3 individual trials. (A) Cells were initially perfused with Hepes-HBSS, then at the time indicated by the bar, the perfusion was switched to the same medium containing BK (a); BK followed by BK $+20 \mu \mathrm{M} \mathrm{LY83583}$ (b). (B) Cells were preincubated with (b) or without (a) $20 \mu \mathrm{M} \mathrm{LY} 83583$ for $10 \mathrm{~min}$, and then image analysis was performed. Cells were initially perfused with Hepes-HBSS, and then switched to $\mathrm{Ca}^{2+}$-free Hepes-HBSS, $\mathrm{Ca}^{2+}$-free Hepes-HBSS with $\mathrm{BK}$, and subsequently $\mathrm{Ca}^{2+}$-free Hepes-HBSS with $\mathrm{BK}+2 \mathrm{mM} \mathrm{BaCl}$. (C) Cells were perfused with Hepes-HBSS and subsequently $1 \mathrm{mM} 8-\mathrm{Br}-\mathrm{cGMP}$ was added at the time indicated by the bar (a) or the perfusion was changed to the same medium containing BK and subsequently BK + $1 \mathrm{mM} 8-\mathrm{Br}-\mathrm{cGMP}$ (b). The concentration of BK was $100 \mathrm{ng} / \mathrm{ml}$. 
A

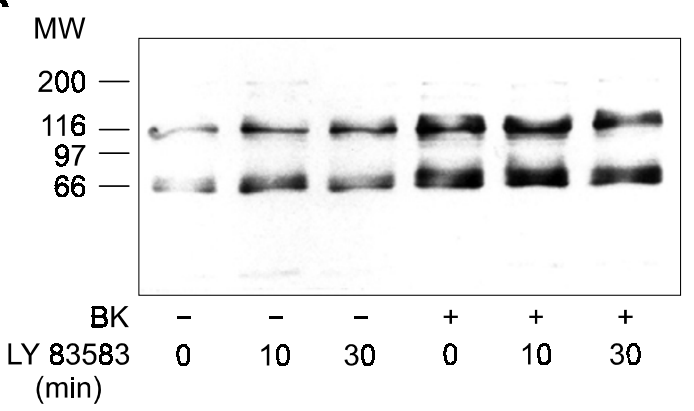

B

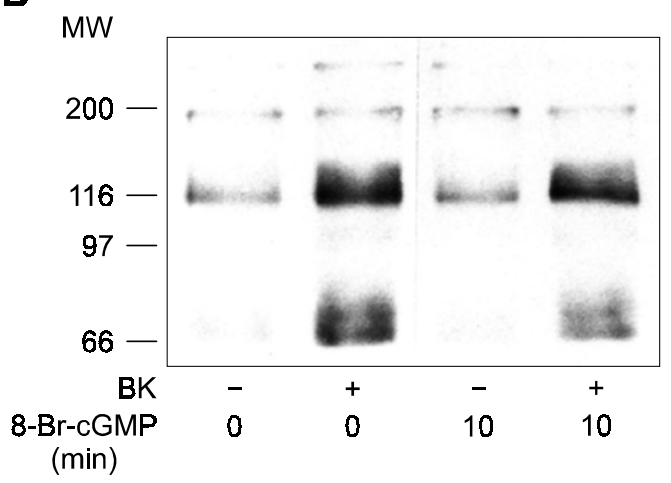

Figure 4. Effects of LY83583 and 8-Br-cGMP on the BK-stimulated tyrosine phosphorylation. (A) Cells were either treated with 20 $\mu \mathrm{M}$ LY83583 alone (lanes 2 and 3) or in combination with BK $(100 \mathrm{ng} / \mathrm{ml}, 1 \mathrm{~min}$, lanes 5 and 6$)$. Subsequently, cells were lysed and subjected to Western blotting. (B) Cells were preincubated with $1 \mathrm{mM} \mathrm{8-Br-cGMP}$ and incubated in the presence or absence of $100 \mathrm{ng} / \mathrm{ml}$ of BK for $1 \mathrm{~min}$ (lanes 3 and 4). Lanes 1 and 2 were from cells that had not been treated with 8-Br-cGMP. Subsequently, cells were lysed and analyzed for tyrosine-phosphorylated proteins as described under Materials and Methods. The results shown are representative of at least 2 experiments,

8-Br-cGMP to either naive cells (Figure 3C, a) or BK-stimulated cells (Figure $3 \mathrm{C}, \mathrm{b}$ ). Addition of $8-\mathrm{Br}-$ cGMP did not change either the basal or the BKstimulated $\left[\mathrm{Ca}^{2+}\right]$.

Next, we examined the effects of LY83583 and $8-\mathrm{Br}-\mathrm{cGMP}$ on the BK-stimulated protein tyrosine phosphorylation (Figure 4). Neither the basal nor the BK-stimulated tyrosine phosphorylation was affected significantly by incubation with either LY83583 (Figure 4A) or 8-Br-cGMP (Figure 4B). These results suggest that, at least in HSWP cells stimulated by $\mathrm{BK}$, cyclic GMP does not have a significant role in regulating either the tyrosine kinase pathway or the BK-stimulated SOCE.

\section{Inhibition of BK-stimulated $\mathrm{Ca}^{2+}$ entry and BK-stimulated tyrosine phosphorylation by econazole, an inhibitor of cytochrome P450}

Cytochrome $\mathrm{P} 450$ has been implicated in the regulation of SOCE based on data showing that various inhibitors of cytochrome P450 enzymes, such as the imidazole antifungal agents, also inhibited SOCE (Alonso et al., 1991; Alvarez et al., 1991; Montero et al., 1991). We investigated whether inhibition of cytochrome P450 activity by econazole, a cytochrome P-450 inhibitor, causes any change in the BK-stimulated $\mathrm{Ca}^{2+}$ responses in HSWP cells. As seen in Figure 5, econazole did not seem to affect the BK-stimulated $\mathrm{Ca}^{2+}$ release since there was no significant difference in the level of the $\mathrm{Ca}^{2+}$ peak between the econazole-treated and untreated groups $[R$ value; $1.56 \pm 0.01$ (mean \pm S.E.; $n=42$ ) in the control and $1.55 \pm 0.02$ (mean \pm S.E; $n=23$ ) in the econazole-treated group].

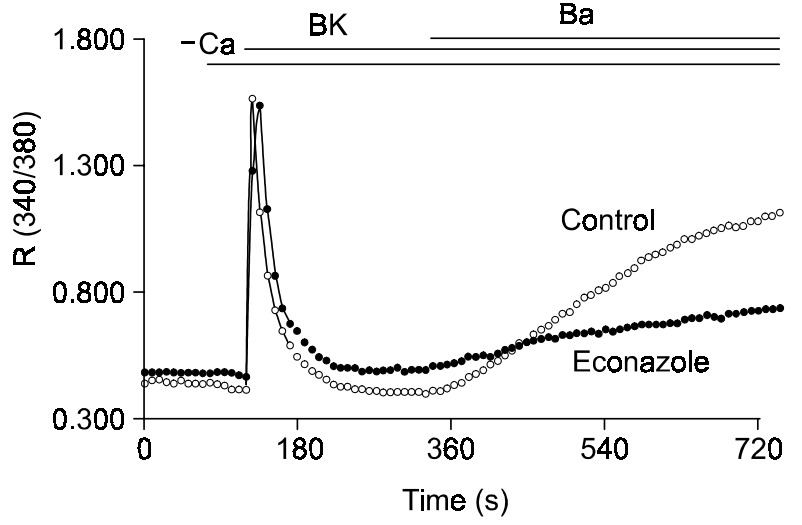

Figure 5. Effects of econazole on the BK-stimulated $\mathrm{Ba}^{2+}$ influx. Each trace shown is from an individual cell in a field of cells (control; $n=42$, econazole; $n=23$ ) and represents a typical response. Essentially as in Figure $2 \mathrm{~B}$, cells were perfused with Hepes-HBSS, and then switched to $\mathrm{Ca}^{2+}$-free medium, $\mathrm{Ca}^{2+}$-free medium containing $100 \mathrm{ng} / \mathrm{ml}$ of BK, and subsequently $\mathrm{Ca}^{2+}$-free medium containing $\mathrm{BK}+2 \mathrm{mM} \mathrm{BaCl}$. For the econazole treated group (filled circle), $10 \mu \mathrm{M}$ econazole was included during the time BK was present. The control trace is plotted as an open circle.

However, the BK-stimulated $\mathrm{Ca}^{2+}$ entry into the cells, measured as $\mathrm{Ba}^{2+}$ entry, was markedly decreased by econazole treatment. The mean rate of $\mathrm{Ba}^{2+}$ entry was $7.1 \pm 1.10 \times 10^{-4}$ (mean \pm S.E.; $n=42$ ) in the control and $1.97 \pm 0.32 \times 10^{-4}$ (mean \pm S.E.; $n=$ $23)$ in the econazole-treated group. These values were statistically different with a $P$ value $<0.001$ (Student $t$ ). These results are comparable to those previously reported (Alonso et al., 1991; Alvarez et 
A

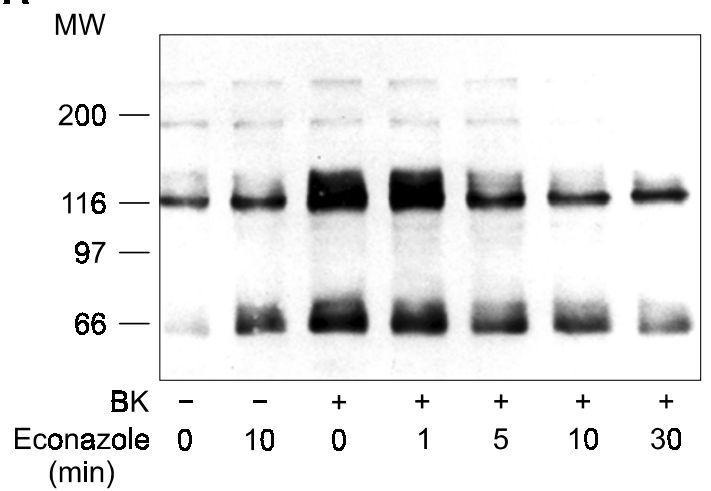

B

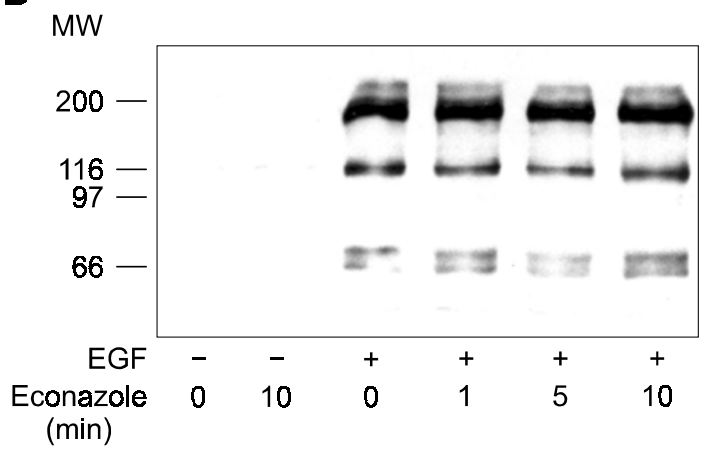

Figure 6. Effects of econazole on the BK-stimulated and EGF-stimulated tyrosine phosphorylation. HSWP cells were analyzed for tyrosine-phosphorylated proteins as described under Materials and Methods. Cells were preincubated with $10 \mu \mathrm{M}$ econazole for the indicated time and stimulated with either $100 \mathrm{ng} / \mathrm{ml}$ of BK for $1 \mathrm{~min}(\mathrm{~A})$ or $100 \mathrm{ng} / \mathrm{ml}$ of EGF for $5 \mathrm{~min}(\mathrm{~B})$. The data shown represent typical results from 3 different experiments.

al., 1991; Moore et al., 1998) and indicate that cytochrome P450 activity may be involved in regulating the BK-stimulated $\mathrm{Ca}^{2+}$ influx.

Since tyrosine kinases also appear to be involved in regulating SOCE (Lee et al., 1993), we tried to define how these two pathways interact along the signaling cascade to regulate plasma membrane $\mathrm{Ca}^{2+}$ entry. One way to address this question was to examine the effect of econazole on tyrosine phosphorylation induced by BK. We found that econazole markedly inhibited tyrosine phosphorylation induced by $\mathrm{BK}$ in a time dependent manner, with maximal inhibition occurring following $10 \mathrm{~min}$ preincubation prior to BK stimulation (Figure 6A). There was no inhibitory effect on protein tyrosine phosphorylation by econazole under the unstimulated conditions (Figure 6A, lane 2). We next addressed the specificity of the inhibitory effects of econazole on BKinduced tyrosine phosphorylation. One way to approach this question was to examine the effect of econazole on the tyrosine phosphorylation that is exerted by epidermal growth factor (EGF), which signals via activation of receptor tyrosine kinases. If inhibition of tyrosine phosphorylation by econazole occurred as a result of general activation of tyrosine phosphatases, econazole would be expected to have a similar inhibitory effect on EGF-stimulated tyrosine phosphorylation. However, econazole preincubation did not affect the tyrosine phosphorylation produced by EGF (Figure 6B). This result indicates that the action of econazole does not seem to involve a general effect on the tyrosine phosphatase activity or nonspecific effects on tyrosine kinases. It is more likely that econazole exhibits its inhibitory effect via a mechanism involving the tyrosine kinase activity activated by $\mathrm{Ca}^{2+}$ store depletion.
One possibility for the inhibitory effect by econazole on tyrosine phosphorylation is that tyrosine phosphorylation is secondary to a rise in the cytosolic $\mathrm{Ca}^{2+}$ concentration and is, therefore, inhibited because $\mathrm{Ca}^{2+}$ entry from the external medium is blocked by econazole. To address this question, we tested whether we could still detect the inhibitory effect of econazole when intracellular $\mathrm{Ca}^{2+}$ is chelated so that $\mathrm{Ca}^{2+}$ entry during $\mathrm{BK}$ stimulation can not contribute to changes in cytosolic $\mathrm{Ca}^{2+}$. To test for this possibility, we incubated cells with the membrane permeable, highly selective $\mathrm{Ca}^{2+}$ chelator BAPTA-AM, which is hydrolyzed into the active $\mathrm{Ca}^{2+}$ chelator BAPTA upon entering the cell. In BAPTAloaded cells, we observed that BK-stimulated $\mathrm{Ca}^{2+}$ responses were completely inhibited (Figure 7A). BK-stimulated tyrosine phosphorylation of both the $130 \mathrm{kDa}$ and $70 \mathrm{kDa}$ proteins was inhibited by approximately $40 \%$ in BAPTA-loaded cells (Figure $7 \mathrm{~B}$, lane 4). These data suggest that a large component of the tyrosine phosphorylation is independent of the rise in the cytosolic $\mathrm{Ca}^{2+}$ concentration. Econazole further decreased BK-stimulated phosphotyrosine levels in BAPTA-loaded cells (Figure 7B, lane 7). Lanes 5 and 6 represent typical results for econazole or econazole and BK, which were observed under the same conditions as for Figure $6 \mathrm{~A}$. These results suggest that a substantial component of the inhibitory effects of econazole on BK-stimulated tyrosine phosphorylation does not result from perturbation of $\mathrm{Ca}^{2+}$ responses, but rather is mediated by another mechanism, presumably by inhibition of the pathway leading to activation of tyrosine kinases. Therefore, the results from these studies indicate that the inhibitory action of econazol on $\mathrm{Ca}^{2+}$ entry probably results from blocking the step 

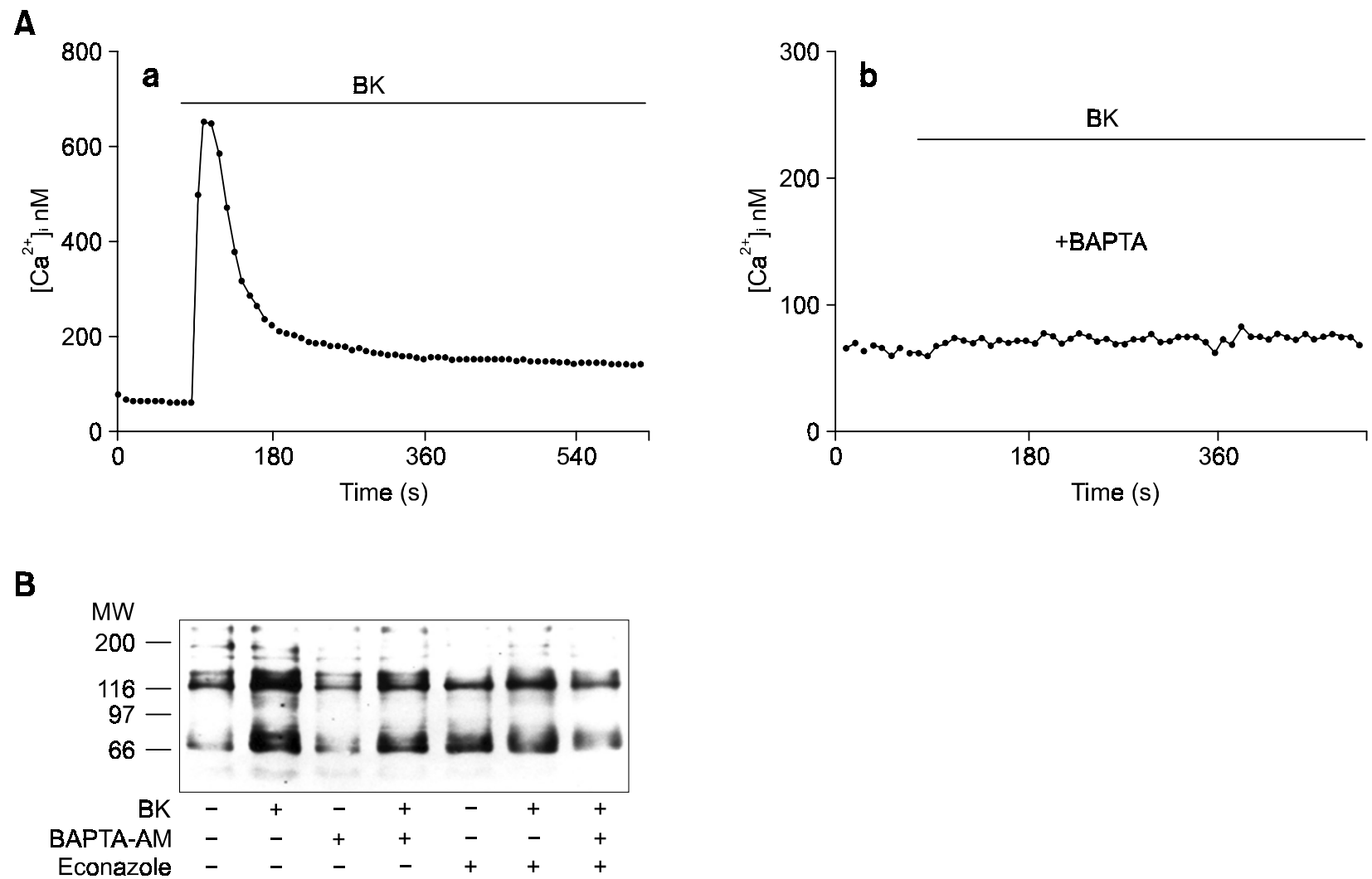

Figure 7. Effects of BAPTA-AM on the $\mathrm{Ca}^{2+}$ response and tyrosine phosphorylation induced by $\mathrm{BK}$. (A) Intracellular $\mathrm{Ca}^{2+}$ responses were monitored by image analysis using fura-2, essentially as in Figure $3 A$. (A-a) BK $(100 \mathrm{ng} / \mathrm{ml})$ causes biphasic calcium responses. (A-b) cells were preincubated with $25 \mu \mathrm{M}$ BAPTA-AM for $30 \mathrm{~min}$, and incubated for additional $90 \mathrm{~min}$ in fresh medium at $37^{\circ} \mathrm{C}$ prior to $\mathrm{BK}$ addition. The trace shown is from an individual cell and represents a typical response of cells from 3 different experiments (total 35 cells). (B) Where indicated, cells were treated with BAPTA-AM in a manner similar to A (lanes 3,4,7) and followed by stimulation with $100 \mathrm{ng} / \mathrm{ml}$ of BK for $1 \mathrm{~min}$ (lane 4,7). For the econazole-treated condition, $10 \mu \mathrm{M}$ econazole was included for 10 min prior to BK stimulation (lanes 5,7). Cells were then lysed and subjected to Western blotting with anti-phosphotyrosine antibodies, as described in Materials and Methods. The results are representative of three identical experiments.
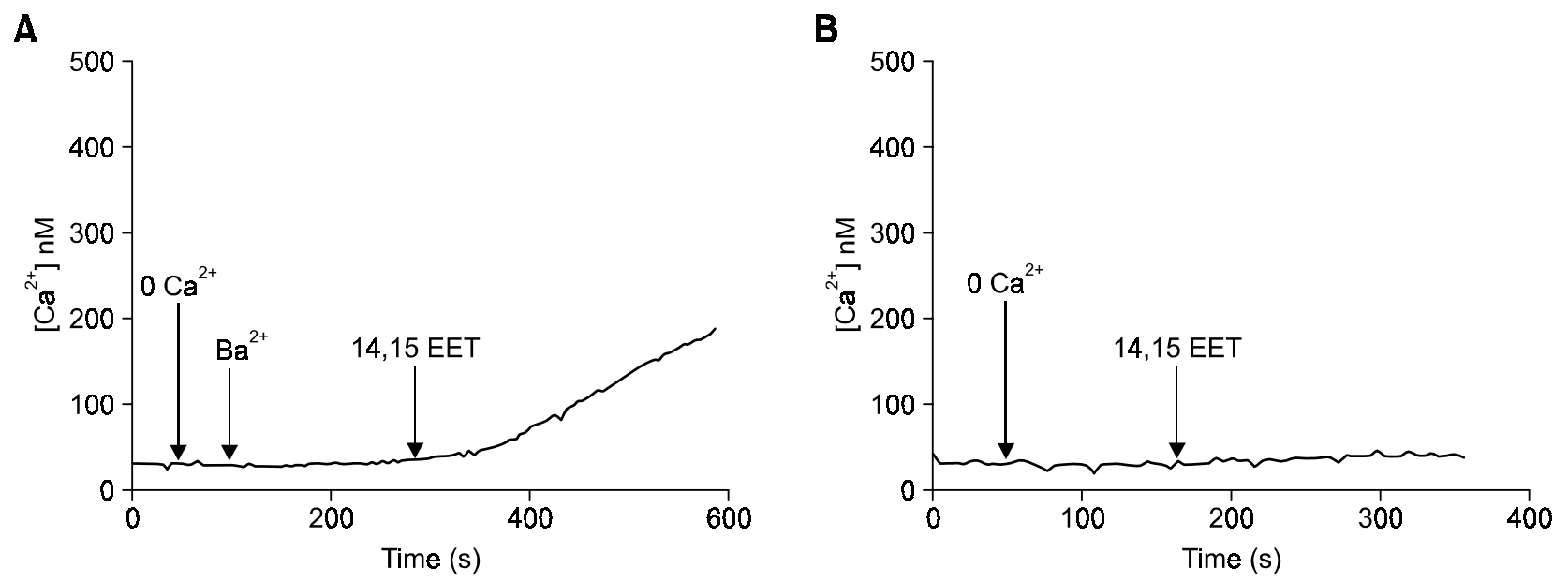

Figure 8. Effect of $14,15 \mathrm{EET}$ on $\mathrm{Ca}^{2+}$ entry in HSWP cells. (A) Cells were perfused with HBSS followed by $\mathrm{Ca}^{2+}$-free HBSS. Then, Ca ${ }^{2+}$-free HBSS containing $2 \mathrm{mM} \mathrm{Ba}^{2+}$ was added to establish the basal Ba ${ }^{2+}$ entry. The perfusion was halted with the cells bathed in $2 \mathrm{mM} \mathrm{Ba}{ }^{2+}$ and $14,15 \mathrm{EET}^{2}$ was added to the chamber to a final dose of $20 \mu \mathrm{M}$. (B) Cells were perfused with HBSS followed by $\mathrm{Ca}^{2+}$-free HBSS. The perfusion was halted with the cells bathed in $\mathrm{Ca}^{2+}$-free medium and 14,15 EET was added to the chamber to a final dose of $60 \mu \mathrm{M}$. 
leading to activation of tyrosine kinases.

\section{Effect of EETs on $\mathrm{Ca}^{2+}$ entry}

If econazole inhibits a pathway leading to the activation of a tyrosine kinase by $\mathrm{Ca}^{2+}$ store depletion, then this implies that a product of cytochrome P450 metabolism of arachidonic acid is stimulating tyrosine kinase activity, and in turn activating SOCE. Therefore, we tested whether various isoforms of EET activate $\mathrm{Ca}^{2+}$ entry in HSWP cells. We examined the effect of the 14, 15 isoform of EET since it has been shown to activate tyrosine kinase activity in renal epithelial cells (Chen et al., 1998).

14, 15 EET stimulated $\mathrm{Ca}^{2+}$ entry as detected by a significant rise in the intracellular uptake of $\mathrm{Ba}^{2+}$ (Figure 8A). This increase in $\mathrm{Ba}^{2+}$ entry due to EET was not secondary to depletion of the intracellular $\mathrm{Ca}^{2+}$ store, since EET did not stimulate $\mathrm{Ca}^{2+}$ release in HSWP cells (Figure 8B). Therefore, a product of cytochrome P450 is capable of stimulating the $\mathrm{Ca}^{2+}$ entry channels used by SOCE, even in the absence of $\mathrm{Ca}^{2+}$ store depletion.

\section{Effect of nitric oxide donors on $\mathrm{Ca}^{2+}$ entry in HSWP cells}

Since store-operated $\mathrm{Ca}^{2+}$ channels have been suggested to be regulated by S-nitrosylation in the presence of nitric oxide donors, such as sodium nitroprusside and GEA3162 (Favre et al., 1998), we tested these agents for their effects on $\mathrm{Ca}^{2+}$ entry in HSWP cells. The addition of $100 \mu \mathrm{M}$ GEA3162 to

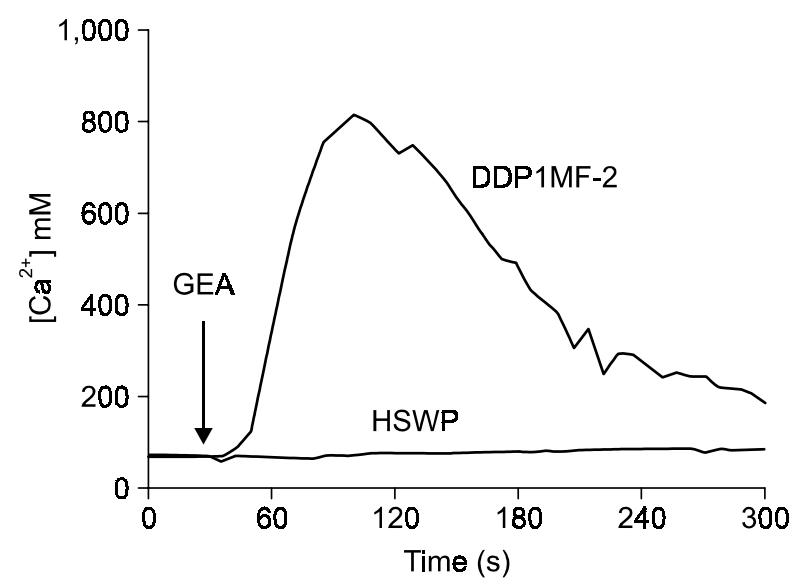

Figure 9. Effect of GEA3162 on $\mathrm{Ca}^{2+}$ levels in HSWP and DDT1MF-2 cells. HSWP cells and DDT1MF-2 cells were loaded with fura-2 and the $\mathrm{Ca}^{2+}$ concentration was monitored by image analysis. Cells were perfused with HBSS and then $100 \mu \mathrm{M}$ GEA3162 was added at the time indicated by the arrow.
HSWP cells resulted in only a modest change in the cytosolic $\mathrm{Ca}^{2+}$ levels (Figure 9). Although difficult to see on the scale of Figure 9, there is usually a rise from the basal level of $50 \mathrm{nM}$ to approximately $70-80$ $\mathrm{nM}$. A number of experiments with sodium nitroprusside (SNP) used at 3 times the dose used by Favre et al. (1998), resulted in approximately the same level of response (data not shown). However, even these small changes in $\mathrm{Ca}^{2+}$ levels in response to GEA3162 or SNP do not have the characteristics one would expect in response to activation of surface $\mathrm{Ca}^{2+}$ channels. For example, when cells are incubated with the NO donors in $\mathrm{Ca}^{2+}$-free medium for $5 \mathrm{~min}$, and then $\mathrm{Ca}^{2+}$ is added back to the cells, only approximately $10 \%$ of the cells in the field respond, and those that do, respond asynchronously over the next five min (data not shown). Also, the responses are not maintained as expected for an influx. A few cells increase in the first minute and return to the base line by the third minute, at which time a few more cells will begin a transient response. All of these observations are in sharp contrast to the results we obtained using DDT 1 MF-2 cells, which were used in the original study by Favre et al. (1998). As shown in Figure 9, after a brief lag, there is a robust rise in the $\mathrm{Ca}^{2+}$ concentration in $\mathrm{DDT}_{1}$ MF2 cells that peaks in the $600-800 \mathrm{nM}$ range, and then declines over time. These data suggest that, in contrast to results in DDT ${ }_{1}$ MF-2 cells, S-nitrosylation due to GEA3162 is not a major regulator of $\mathrm{Ca}^{2+}$ entry in SOCE of HSWP cells.

\section{Phorbol 12-myristate 13-acetate (PMA) inhibits the $\mathrm{Ca}^{2+}$ plateau that is induced by thapsigargin by a mechanism involving $\mathrm{Ca}^{2+}$ extrusion}

BK has also been shown to stimulate protein kinase $C$ activity in HSWP cells via generation of diacyIglycerol, which is an activator of protein kinase $\mathrm{C}$ (Hardie, 2003). Therefore, we next examined whether protein kinase $C$ activity is involved in regulating the SOCE. A similar approach was used as that described above except that thapsigargin was used as a stimulus. One of the reasons to use thapsigargin in this set of experiments was that it produces a more homogeneous $\mathrm{Ca}^{2+}$ response than $\mathrm{BK}$ in terms of the level of $\mathrm{Ca}^{2+}$ plateaus. Thapsigargin has been shown to mobilize intracellular $\mathrm{Ca}^{2+}$ by inhibiting microsomal $\mathrm{Ca}^{2+}$-ATPases (Thastrup et al., 1994) and, thereby, activates $\mathrm{Ca}^{2+}$ entry (Takemura et al., 1989). Thapsigargin stimulates tyrosine phosphorylation in HSWP cells and thapsigargin-stimulated $\mathrm{Ca}^{2+}$ entry is inhibited by tyrosine kinase inhibitors (Lee et al., 1993), suggesting that thapsigargin stimulates $\mathrm{Ca}^{2+}$ entry via a mechanism similar to that induced by BK. When we applied $200 \mathrm{nM}$ 

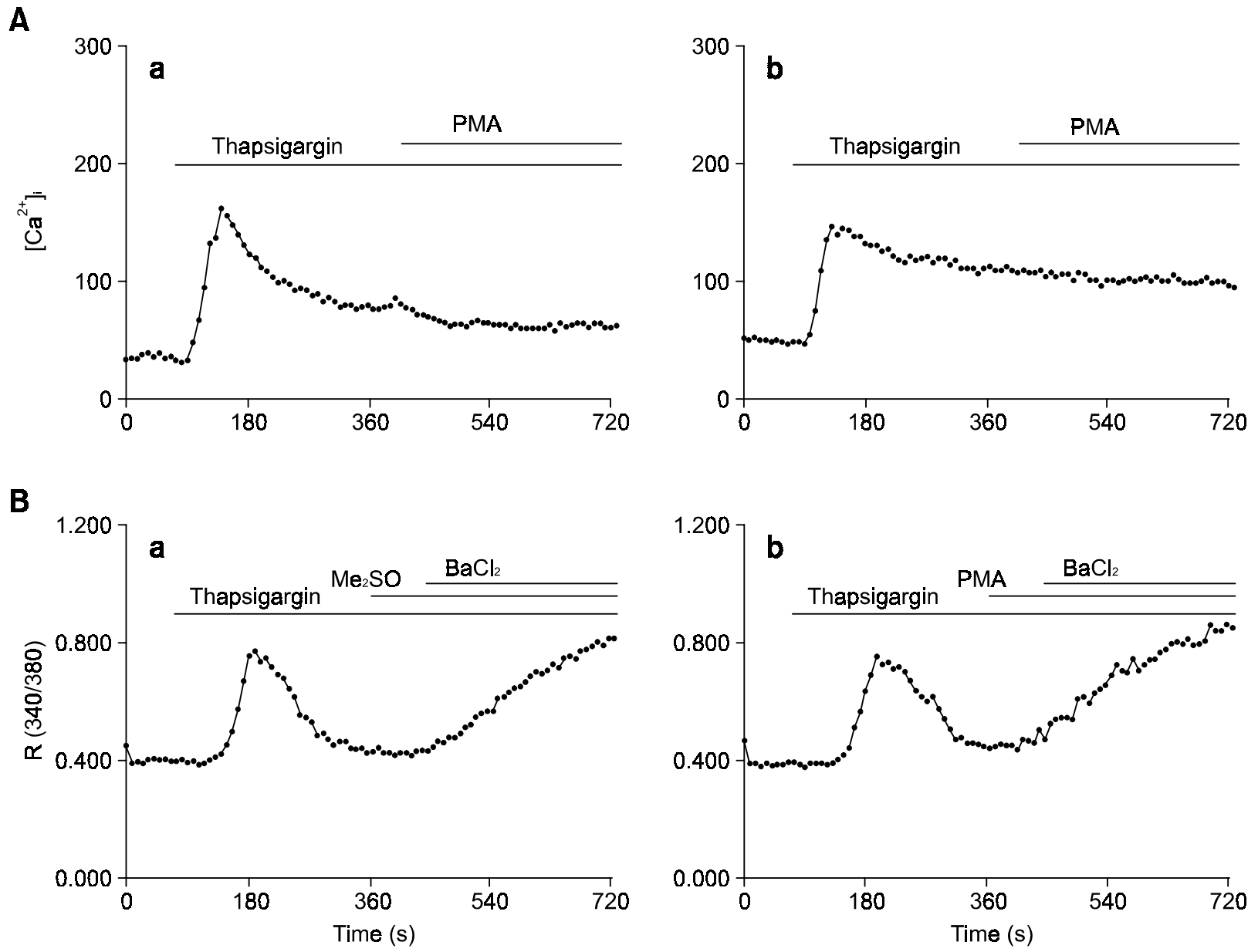

Figure 10. Effects of PMA on the thapsigargin-simulated $\mathrm{Ca}^{2+}$ response. (A) Cells were either preincubated with (b) or without (a) $200 \mathrm{nM}$ PMA for $24 \mathrm{~h}$ prior to experiments. Subsequently, cells were loaded with fura-2 and image analysis was carried out as described under Materials and Methods. Initially, cells were perfused with Hepes-HBSS and, at the time indicated by the bar, the perfusion was changed to the same medium containing $1 \mu \mathrm{g} / \mathrm{ml}$ of thapsigargin, and subsequently $1 \mu \mathrm{g} / \mathrm{ml}$ of thapsigargin $+200 \mathrm{nM} \mathrm{PMA}$. (B) Cells were initially perfused with $\mathrm{Ca}^{2+}$-free Hepes-HBSS and, at the time indicated by the bar, the perfusion was switched to the same medium containing $1 \mu \mathrm{g} / \mathrm{ml}$ of thapsigargin, $1 \mu \mathrm{g} / \mathrm{ml}$ of thapsigargin $+0.1 \% \mathrm{Me}_{2} \mathrm{SO}$ (a) or $1 \mu \mathrm{g} / \mathrm{ml}$ of thapsigargin $+200 \mathrm{nM} \mathrm{PMA}(\mathrm{b})$, and subsequently $1 \mu \mathrm{g} / \mathrm{ml}$ of thapsigargin $+0.1 \% \mathrm{Me}_{2} \mathrm{SO}+$ $2 \mathrm{mM} \mathrm{BaCl}_{2}(\mathrm{a})$ or $1 \mu \mathrm{g} / \mathrm{ml}$ of thapsigargin $+200 \mathrm{nM} \mathrm{PMA}+2 \mathrm{mM} \mathrm{BaCl}_{2}(\mathrm{~b})$.

PMA, which rapidly stimulates protein kinase $\mathrm{C}$ activity, to the $\mathrm{Ca}^{2+}$ plateau phase (Figure $10 \mathrm{~A}-\mathrm{a}$ ), a slight decrease in the $\mathrm{Ca}^{2+}$ level was consistently detected. The mean ( \pm S.D.) plateau $\left[\mathrm{Ca}^{2+}\right]_{i}$ was $112.3 \pm 4.05 \mathrm{nM}$ before PMA addition whereas that obtained after PMA addition was $71.4 \pm 11.74 \mathrm{nM}$ $(n=39)$. The difference between the untreated group and the PMA-treated group was statistically significant $(P<0.0001)$. This result indicates that PMA-sensitive protein kinase $C$ may be involved in either inhibiting $\mathrm{Ca}^{2+}$ entry or activating $\mathrm{Ca}^{2+}$ extrusion. Since PMA-sensitive protein kinase $\mathrm{C}$ activity can be depleted by prolonged treatment of cells with PMA (Etscheid et al., 1991; Simonson and Dunn, 1991), we examined whether the absence of this activity affected the $\mathrm{Ca}^{2+}$ entry induced by thapsigargin. The results shown in Figure 10A-b indicate that down regulation of PMA-sensitive protein kinase $C$ did not markedly affect the $\mathrm{Ca}^{2+}$ release stimulated by thapsigargin, since there was no significant difference in the level of the $\mathrm{Ca}^{2+}$ peaks between the control [a, $163 \pm 17.1 \mathrm{nM}(n=$ 33)] and protein kinase C-depleted cells [b, $157 \pm$ $13.2 \mathrm{nM}(n=35)]$. In agreement with protein kinase $C$ downregulation, no effect was observed on the thapsigargin-induced $\mathrm{Ca}^{2+}$ plateaus after acute addition of PMA in PMA-treated cells (b). This effect was further investigated where the effect of PMA on the $\mathrm{Ca}^{2+}$ influx was directly examined using the $\mathrm{Ba}^{2+}$ protocol described above (Figure 10B). The mean rate of $\mathrm{Ba}^{2+}$ entry, measured from the slope of the $\mathrm{Ba}^{2+}$-containing phase stimulated by thapsigargin 


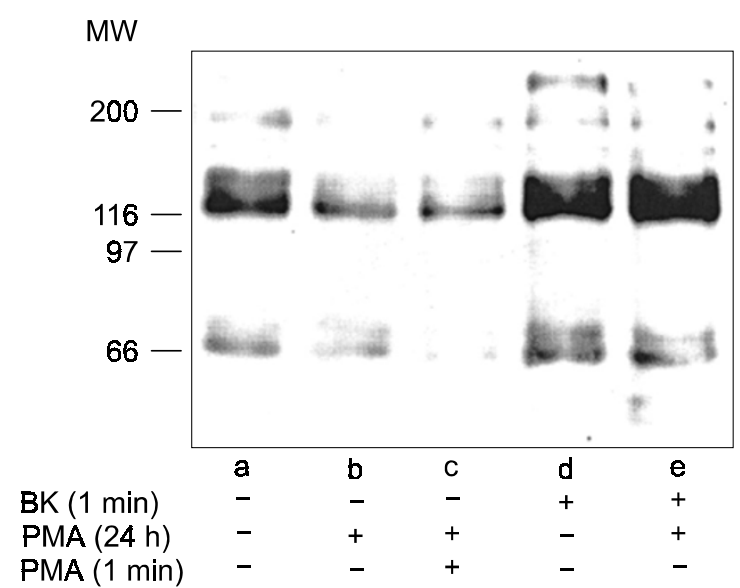

Figure 11. Effects of PMA on the BK-stimulated tyrosine phosphorylation. HSWP cells were preincubated with $200 \mathrm{nM}$ PMA for $24 \mathrm{~h}(\mathrm{~b}, \mathrm{c}, \mathrm{e})$ and subsequently stimulated with either $200 \mathrm{nM}$ PMA (c) or $100 \mathrm{ng} / \mathrm{ml}$ of BK for $1 \mathrm{~min}(\mathrm{e})$. a and d represent, respectively, the basal level and the BK-stimulated level of tyrosine phosphorylation in the absence of PMA treatment. Cells were then lysed and Western blotting was performed as described under Materials and Methods.

was $12.51 \times 10^{-4}(n=38)$ in the absence of PMA, and $13.41 \times 10^{-4}(n=38)$ in the presence of PMA. The difference between these groups was not statistically significant. These results indicate that PMA-sensitive protein kinase $\mathrm{C}$ may regulate $\mathrm{Ca}^{2+}$ responses through a mechanism involving $\mathrm{Ca}^{2+}$ extrusion from the cytosol, but does not directly regulate $\mathrm{Ca}^{2+}$ entry.

We next examined whether PMA-sensitive protein kinase $C$ regulates protein tyrosine phosphorylation. As shown in Figure 11, BK-stimulated tyrosine phosphorylation in the protein kinase C-down regulated cells (e) was comparable to that observed in the untreated cells (d). It was noticed that a long treatment with PMA caused a slight decrease in the phosphotyrosine level of $130 \mathrm{kDa}$ proteins (b), which may indicate that PMA-sensitive protein kinase C plays a role in regulating tyrosine phosphorylation under basal, nonstimulated conditions. Thus, these results demonstrate that the activation of protein kinase $C$ does not affect the activation of tyrosine kinases or tyrosine phosphorylation stimulated by BK. In addition, PMA-sensitive protein kinase $C$ is probably involved in $\mathrm{Ca}^{2+}$ homeostasis by activating $\mathrm{Ca}^{2+}$ extrusion mechanisms.

\section{Discussion}

We have examined the role of intracellular signaling molecules in regulating SOCE and protein tyrosine phosphorylation in human fibroblast cells. The data presented here suggest that SOCE is regulated by either tyrosine kinases or tyrosine phosphorylation (Figure 2), but not by cyclic GMP (Figure 3), nitric oxide (Figure 9), or diacylglycerol acting via a PKC pathway (Figure 10). The involvement of cytochrome $\mathrm{P} 450$ in regulating $\mathrm{Ca}^{2+}$ entry is somewhat complicated since econazole, which inhibits cytochrome P450 activity, also inhibits tyrosine phosphorylation of a number of proteins in HSWP cells (Figure 6). This observation confirms a previous report that econazole reduces agonist induced tyrosine phosphorylation (Sargeant et al., 1994a) and extends the report by demonstrating that the inhibitory effect of econazol on tyrosine phosphorylation is not secondary to perturbation of $\mathrm{Ca}^{2+}$ entry (Figure 7B) and is not the result of a general inhibition of tyrosine phosphorylation since it has no effect on the EGF induced tyrosine phosphorylation (Figure 6B). Therefore, the remaining possibilities are either that econazole is a nonspecific inhibitor of tyrosine kinases or that econazole blocks cytochrome P450 activity that acts upstream of tyrosine kinases in the signaling cascade leading to activation of $\mathrm{Ca}^{2+}$ entry. Alternatively, we cannot rule out the possibility that the effects of econazole seen on both tyrosine phosphorylation and $\mathrm{Ca}^{2+}$ entry are not related and that econazole nonspecifically inhibits both events. For example, other reports indicate that the inhibitory action of econazol on $\mathrm{Ca}^{2+}$ entry may be accomplished by a mechanism that does not involve cytochrome P450 activity (Vostal and Fratantoni, 1993; Koch et al., 1994). These published results indicate that cytochrome P450 activity may not be critical for regulating SOCE and an alternative explanation may be that econazole exerts its inhibitory effect by an alternative mechanism, perhaps by inhibiting tyrosine kinase activity.

We did not observe any modulatory effect of cyclic GMP on SOCE, consistent with previous reports involving several cell types (Fasolato et al., 1993; Randriamampita and Tsien, 1993), but contrary to reports involving pancreatic acinar cells where the role of cyclic GMP in stimulating SOCE is well supported (Pandol and Schoeffield-Payne, 1990; Bahnson et al., 1993; Xu et al., 1994), or in platelets where the role of cGMP in inhibiting SOCE has been reported (Rosado et al., 2001). Xu et al. (1994) hypothesized that nitric-oxide synthase and guanylate cyclase operate in series to activate $\mathrm{Ca}^{2+}$ entry controlled by $\mathrm{Ca}^{2+}$ store depletion and showed that cyclic GMP has a dual effect on $\mathrm{Ca}^{2+}$ entry. Increasing the cyclic GMP concentration up to 10 -fold above control levels activated $\mathrm{Ca}^{2+}$ entry while further increases up to 80 -fold above control levels inhibited $\mathrm{Ca}^{2+}$ entry. The absence of the effects seen by other investigators might be due, the authors guessed, to application of high and inhibitory con- 
centrations of cyclic GMP to the cells. One could argue that this could explain the lack of effect for the membrane permeable cyclic GMP analogue 8-BrcGMP on basal or BK-stimulated $\mathrm{Ca}^{2+}$ entry (Figure $3 \mathrm{C})$. However, the finding that the guanylate cyclase inhibitor LY83583 did not affect BK-stimulated $\mathrm{Ca}^{2+}$ entry favors the conclusion that cyclic GMP does not play a significant role in regulating $\mathrm{Ca}^{2+}$ entry. Our observations in human fibroblasts do not call into question the role of cyclic GMP in the stimulation of $\mathrm{Ca}^{2+}$ entry in pancreatic acinar cells or its role in inhibition of SOCE in platelets (Rosado et al., 2001) or vascular endothelial cells (Kwan et al., 2000). Rather, our results suggest that there may be a variety of methods by which different cells achieve activation (or modulation) of $\mathrm{Ca}^{2+}$ entry pathways.

Our results and previous findings (Lee et al., 1993) strongly suggest involvement of either tyrosine kinases or tyrosine phosphorylation in the regulation of SOCE. SOCE is subject to regulation by tyrosine phosphatases (Figure 2), based on the effect of vanadate on tyrosine phosphorylation and BK-stimulated $\mathrm{Ba}^{2+}$ entry. Previously, vanadate was shown to have a number of effects other than inhibiting tyrosine phosphatase activity. Stimulation of $\mathrm{PIP}_{2}$ hydrolysis via activation of a G-protein-linked phospholipase C (Paris et al., 1987; Paris and Pouyssegur, 1987) and inhibition of the plasma membrane $\mathrm{Ca}^{2+}$ pump are such examples. One can argue that our results are due to nonspecific activation of phospholipase $\mathrm{C}$ and/or inhibition of the $\mathrm{Ca}^{2+}$ pump, since these effects can also lead to enhancement of the intracellular $\mathrm{Ca}^{2+}$ concentration. However, it is very unlikely that this is the case. We previously have detected $\mathrm{Ca}^{2+}$ mobilization by vanadate in HSWP cells (data not shown), which agrees with the previous findings that vanadate stimulates phospholipase $\mathrm{C}$ activity. However, the $\mathrm{Ca}^{2+}$ release produced by vanadate was small compared to that induced by BK (data not shown) and the $\mathrm{Ca}^{2+}$ peak generated by a combination of vanadate and $\mathrm{BK}$ was not greater than that induced by BK alone (Figure 2B), which suggests that $\mathrm{BK}$ and vanadate release $\mathrm{Ca}^{2+}$ from the same intracellular $\mathrm{Ca}^{2+}$ pools. This eliminates the possibility that augmentation of BK-stimulated $\mathrm{Ca}^{2+}$ influx by vanadate is due to additional $\mathrm{Ca}^{2+}$ release by vanadate. Furthermore, the effect seen on the BK-stimulated $\mathrm{Ba}^{2+}$ influx by vanadate was not due to inhibition of the $\mathrm{Ca}^{2+}$ pump since $\mathrm{Ba}^{2+}$ can not be pumped by $\mathrm{Ca}^{2+}$ ATPases. These results suggest that the effect of vanadate on $\mathrm{Ca}^{2+}$ entry is through regulation of protein tyrosine phosphorylation involving tyrosine phosphatase activity.

Neither the mechanism for activation of tyrosine kinases nor the identity of tyrosine kinases responsi- ble for regulation of $\mathrm{Ca}^{2+}$ entry is known. While our data indicate that a rise in the cytosolic $\mathrm{Ca}^{2+}$ concentration following depletion of internal stores is necessary for full activation of tyrosine kinase activity (Figure 7B), it is also clear that there is a large component of the BK-stimulated tyrosine phosphorylation that is independent of a rise in the cytosolic $\mathrm{Ca}^{2+}$ concentration, since BAPTA-AM failed to inhibit approximately $60 \%$ of the BK-induced tyrosine phosphorylation (Figure 7B). This result indicates that there are at least two mechanisms for activation of tyrosine kinases by BK in HSWP cells; one dependent on and the other independent of a rise in the cytosolic $\mathrm{Ca}^{2+}$ concentration. The tyrosine phosphorylation that is independent of a rise in the cytosolic $\mathrm{Ca}^{2+}$ concentration may represent the activation of tyrosine kinases in direct response to a messenger generated by $\mathrm{Ca}^{2+}$ store depletion. This would be consistent with observations in platelets where a store-depletion-dependent increase in protein tyrosine phosphorylation is observed (Sargeant et al., 1994b). In studies from other laboratories, $\mathrm{Ca}^{2+}$-dependence on tyrosine phosphorylation was reported in thrombin-stimulated $\mathrm{BC}_{3} \mathrm{H} 1$ cells (Offermanns et al., 1993) and angiotensin-stimulated WB cells (Huckle et al., 1990). In contrast, bombesin stimulation of tyrosine phosphorylation of the two substrates pp125 $5^{\mathrm{FAK}}$ and paxillin was shown by Rozengurt's group to be independent of $\mathrm{Ca}^{2+}$ (SinnettSmith et al., 1993; Zachary et al., 1993). The contradictory results from these reports together with our results concerning the $\mathrm{Ca}^{2+}$ independence of a large component of tyrosine phosphorylation suggest that distinct mechanisms are operative in activating tyrosine phosphorylation events. We also eliminated the possibility of protein kinase $C$ being a regulator of either tyrosine phosphorylation or tyrosine kinases stimulated by BK. Further research will help characterize the mechanism for activation of tyrosine kinases responsible for $\mathrm{Ca}^{2+}$ entry.

Regarding the identity of tyrosine kinases involved in the regulation of $\mathrm{Ca}^{2+}$ entry, we have shown in a previous study that the two nonreceptor tyrosine kinases $p p 60^{\mathrm{src}}$ and $\mathrm{pp} 125^{\mathrm{FAK}}$ are present and activated by BK in HSWP cells (Lee and Villereal, 1996). Enhanced $\mathrm{Ca}^{2+}$ entry in cells overexpressing pp60 ${ }^{\mathrm{v} \text {-src }}$ (Niklinska et al., 1992) and pp59 fyn (Cooke et al., 1991) has previously been reported. In addition, we previously reported a reduction of SOCE in fibroblasts isolated from src-deficient mice, as compared to fibroblasts isolated from wild-type mice (Babnigg et al., 1997). These findings demonstrate that SOCE can be regulated by tyrosine kinases, and suggest that src family tyrosine kinases are involved in this process (Kawasaki et al., 2006).

At present, it is not clear at which step tyrosine 
kinase plays a role in BK-mediated $\mathrm{Ca}^{2+}$ entry pathways. Tyrosine phosphorylation in platelets was enhanced following depletion of internal $\mathrm{Ca}^{2+}$ stores, with the principal substrate being a $130 \mathrm{kDa}$ protein (Vostal et al., 1991). Although the authors did not test the hypothesis, they did speculate that one of the roles of phosphorylated $130 \mathrm{kDa}$ proteins was to regulate plasma membrane $\mathrm{Ca}^{2+}$ permeability. Our results are consistent with the hypothesis that tyrosine kinase activity plays a role in $\mathrm{Ca}^{2+}$ entry pathways, although the mechanism of activation of plasma membrane $\mathrm{Ca}^{2+}$ channels is not known. It is possible that tyrosine kinases activate $\mathrm{Ca}^{2+}$ entry by directly phosphorylating $\mathrm{Ca}^{2+}$ channels. An alternative explanation for tyrosine kinase regulation of SOCE has been put forward in terms of the secretion-like coupling model that suggests that the cytoskeleton controls the interaction between the endoplasmic reticulum and the plasma membrane, which leads to de novo coupling of the $\mathrm{IP}_{3}$ receptors and the calcium entry channels (Rosado et al., 2005). Based on this model and the known role of tyrosine phosphorylations in remodeling the cytoskeleton, one can speculate that activation of tyrosine kinases in response to store depletion plays an important role in this process.

The mechanism for enhancement of tyrosine phosphorylation is not known, although it is clear from the BAPTA experiments (Figure 7) that enhanced phosphorylation can take place in the absence of a rise in the amount of cytosolic $\mathrm{Ca}^{2+}$. One intriguing possibility is that, following depletion of internal $\mathrm{Ca}^{2+}$ stores, production of EET isoforms, via cytochrome P450 activity, leads to a stimulation of tyrosine kinase activity similar to that observed after addition of exogenous EET to renal epithelial cells (Chen et al., 1998) and aortic endothelial cells (Hoebel et al., 1998). In the aortic endothelial cells, addition of arachidonic acid also stimulated tyrosine kinase activity. This effect was blocked by inhibitors of P450 activity, indicating that the effects of econazole we see in HSWP cells may be at the level of production of EET isoforms rather than as a direct block of the tyrosine kinase. Studies in renal epithelial cells have suggested that the tyrosine phosphorylation induced by 14,15 EET is mediated by src kinase, since EET stimulated src kinase activity (Chen et al., 1998), and that overexpression of C-terminal src kinase blocks 14,15 EET-induced tyrosine phosphorylation (Chen et al., 2000). Therefore, it is tempting to speculate that the cytochrome P450 enzyme activated by $\mathrm{Ca}^{2+}$ store depletion generates EET isoforms, which then activate srcfamily tyrosine kinases and subsequently open store-operated calcium channels. Experiments are planned to investigate this idea.
The physiological role of tyrosine kinase-regulated $\mathrm{Ca}^{2+}$ entry pathways is not known. However, given the fact that tyrosine phosphorylation can serve as a mitogenic signal in cells following activation of $G$ protein-coupled receptors (Seckl and Rozengurt, 1993) and the fact that the presence of extracellular $\mathrm{Ca}^{2+}$ is required for mitogenesis, activation of the $\mathrm{Ca}^{2+}$ influx pathway by tyrosine kinases probably potentiates or synergizes with mitogenic signals generated by growth factor receptors. Our results indicate that multiple pathways probably operate in a single cell type leading to activation of $\mathrm{Ca}^{2+}$ entry and that some of these signaling pathways are more prominently involved in regulating calcium entry in different cell types.

\section{Acknowledgement}

We would like to thank Dr. John R. Falck, Department of Biochemistry, University of Texas Southwestern, Dallas, TX, for generously providing the 14,15 EET isoforms. This work was supported by NIH grant GM 54500, a grant from the National R\&D Program for Cancer Control, Ministry of Health \& Welfare, Republic of Korea (0420310-1). And National Nuclear R\&D Program of the Ministry of Science and Technology of Korea (Grant BAERI). K.-M. Lee and S.-W. Son are supported by a Korea University Grant.

\section{References}

Alonso MT, Alvarez J, Montero M, Sanchez A, Garcia-Sancho $\mathrm{J}$. Agonist-induced $\mathrm{Ca}^{2+}$ influx into human platelets is secondary to the emptying of intracellular $\mathrm{Ca}^{2+}$ stores. Biochem J 1991;280:783-9

Alvarez J, Montero M, Garcia-Sancho J. Cytochrome P-450 may link intracellular $\mathrm{Ca}^{2+}$ stores with plasma membrane $\mathrm{Ca}^{2+}$ influx. Biochem J 1991;274:193-7

Babnigg G, Bowersox SR, Villereal ML. The role of pp60c-src in the regulation of calcium entry via store-operated calcium channels. J Biol Chem 1997;272:29434-7

Bahnson TD, Pandol SJ, Dionne VE. Cyclic GMP modulates depletion-activated $\mathrm{Ca}^{2+}$ entry in pancreatic acinar cells. J Biol Chem 1993;268:10808-12

Bird GS, Putney JW Jr. Inhibition of thapsigargin-induced calcium entry by microinjected guanine nucleotide analogues. Evidence for the involvement of a small G-protein in capacitative calcium entry. J Biol Chem 1993;268:21486-8

Bird GS, Aziz O, Lievremont JP, Wedel BJ, Trebak M, Vazquez G, Putney JW, Jr. Mechanisms of phospholipase C-regulated calcium entry. Curr Mol Med 2004;4:291-301

Byron $\mathrm{KL}$, Villereal ML. Mitogen-induced $\left[\mathrm{Ca}^{2+}\right]_{i}$ changes in individual human fibroblasts. Image analysis reveals asynchronous responses which are characteristic for different 
mitogens. J Biol Chem 1989;264:18234-9

Chen JK, Falck JR, Reddy KM, Capdevila J, Harris RC. Epoxyeicosatrienoic acids and their sulfonimide derivatives stimulate tyrosine phosphorylation and induce mitogenesis in renal epithelial cells. J Biol Chem 1998;273:29254-61

Chen JK, Capdevila J, Harris RC. Overexpression of C-terminal Src kinase blocks 14, 15-epoxyeicosatrienoic acid-induced tyrosine phosphorylation and mitogenesis. J Biol Chem 2000;275:13789-92

Cooke MP, Abraham KM, Forbush KA, Perlmutter RM. Regulation of $T$ cell receptor signaling by a src family protein-tyrosine kinase (p59fyn). Cell 1991;65:281-91

Davis MJ, Sharma NR. Calcium-release-activated calcium influx in endothelium. J Vasc Res 1997;34:186-95

Etscheid BG, Albert KA, Villereal ML, Palfrey HC. Transduction of the bradykinin response in human fibroblasts: prolonged elevation of diacylglycerol level and its correlation with protein kinase C activation. Cell Regul 1991;2:229-39

Fasolato C, Hoth M, Penner R. A GTP-dependent step in the activation mechanism of capacitative calcium influx. J Biol Chem 1993;268:20737-40

Favre CJ, Ufret-Vincenty CA, Stone MR, Ma HT, Gill DL. Ca ${ }^{2+}$ pool emptying stimulates $\mathrm{Ca}^{2+}$ entry activated by S-nitrosylation. J Biol Chem 1998;273:30855-8

Graier WF, Simecek S, Sturek M. Cytochrome P450 mono-oxygenase-regulated signalling of $\mathrm{Ca}^{2+}$ entry in human and bovine endothelial cells. J Physiol 1995;482:259-74

Hardie RC. Regulation of TRP channels via lipid second messengers. Annu Rev Physiol 2003;65:735-59 Epub 2002 May 1.

Hoebel BG, Steyrer E, Graier WF. Origin and function of epoxyeicosatrienoic acids in vascular endothelial cells: more than just endothelium-derived hyperpolarizing factor? Clin Exp Pharmacol Physiol 1998;25:826-30

Huckle WR, Prokop CA, Dy RC, Herman B, Earp S. Angiotensin II stimulates protein-tyrosine phosphorylation in a calcium-dependent manner. Mol Cell Biol 1990;10:6290-8

Irvine RF. Inositol tetrakisphosphate as a second messenger: confusions, contradictions, and a potential resolution. Bioessays 1991;13:419-27

Jaconi ME, Lew DP, Monod A, Krause $\mathrm{KH}$. The regulation of store-dependent $\mathrm{Ca}^{2+}$ influx in $\mathrm{HL}-60$ granulocytes involves GTP-sensitive elements. J Biol Chem 1993;268:26075-8

Kawasaki BT, Liao Y, Birnbaumer L. Role of Src in C3 transient receptor potential channel function and evidence for a heterogeneous makeup of receptor- and store-operated $\mathrm{Ca}^{2+}$ entry channels. Proc Natl Acad Sci USA 2006;103:335-40

Koch BD, Faurot GF, Kopanitsa MV, Swinney DC. Pharmacology of a $\mathrm{Ca}(2+)$-influx pathway activated by emptying the intracellular $\mathrm{Ca}^{2+}$ stores in $\mathrm{HL}-60$ cells: evidence that a cytochrome P-450 is not involved. Biochem J 1994;302:187-90

Krutetskaia ZI, Levedev OE, Tiushev VE, Krutetskaia NI, Roshchina NG. Effect of tyrosine kinase and tyrosine phosphatase inhibitors on ATP- and thapsigargin-induced $\mathrm{CA}^{2+}$ entry in rat peritoneal macrophages. Tsitologiia 1997; 39:164-176.

Kwan HY, Huang Y, Yao X. Store-operated calcium entry in vascular endothelial cells is inhibited by cGMP via a protein kinase G-dependent mechanism. J Biol Chem 2000;275: 6758-63

Lee KM, Toscas K, Villereal ML. Inhibition of bradykinin- and thapsigargin-induced $\mathrm{Ca}^{2+}$ entry by tyrosine kinase inhibitors. J Biol Chem 1993;268:9945-8

Lee KM, Villereal ML. Tyrosine phosphorylation and activation of pp60c-src and pp125FAK in bradykinin-stimulated fibroblasts. Am J Physiol 1996;270:C1430-7

Marhaba R, Mary F, Pelassy C, Stanescu AT, Aussel C, Breittmayer JP. Tyrphostin A9 inhibits calcium releasedependent phosphorylations and calcium entry via calcium release-activated channel in Jurkat T cells. J Immunol 1996; 157:1468-73

Montero M, Alvarez J, Garcia-Sancho J. Agonist-induced Ca ${ }^{2+}$ influx in human neutrophils is secondary to the emptying of intracellular calcium stores. Biochem J 1991;277:73-9

Moore TM, Brough GH, Babal P, Kelly JJ, Li M, Stevens T. Store-operated calcium entry promotes shape change in pulmonary endothelial cells expressing Trp1. Am J Physiol 1998;275:L574-82

Mulsch A, Busse R, Liebau S, Forstermann U. LY 83583 interferes with the release of endothelium-derived relaxing factor and inhibits soluble guanylate cyclase. J Pharmacol Exp Ther 1988;247:283-8

Niklinska BB, Yamada H, O'Shea JJ, June CH, Ashwell JD. Tyrosine kinase-regulated and inositol phosphate-independent $\mathrm{Ca}^{2+}$ elevation and mobilization in T cells. J Biol Chem 1992;267:7154-9

Offermanns S, Bombien E, Schultz G. Thrombin $\mathrm{Ca}(2+)-$ dependently stimulates protein tyrosine phosphorylation in BC3H1 muscle cells. Biochem J 1993;290:27-32

Pandol SJ, Schoeffield-Payne MS. Cyclic GMP mediates the agonist-stimulated increase in plasma membrane calcium entry in the pancreatic acinar cell. J Biol Chem 1990; 265:12846-53

Parekh AB, Putney JW Jr. Store-operated calcium channels. Physiol Rev 2005;85:757-810

Paris S, Pouyssegur J. Further evidence for a phospholipase C-coupled $G$ protein in hamster fibroblasts. Induction of inositol phosphate formation by fluoroaluminate and vanadate and inhibition by pertussis toxin. J Biol Chem 1987;262:1970-6

Paris S, Chambard JC, Pouyssegur J. Coupling between phosphoinositide breakdown and early mitogenic events in fibroblasts. Studies with fluoroaluminate, vanadate, and pertussis toxin. J Biol Chem 1987;262:1977-83

Putney JW Jr, McKay RR. Capacitative calcium entry channels. Bioessays 1999;21:38-46

Randriamampita C, Tsien RY. Emptying of intracellular $\mathrm{Ca}^{2+}$ stores releases a novel small messenger that stimulates $\mathrm{Ca}^{2+}$ influx. Nature 1993;364:809-14 
Rosado JA, Porras T, Conde M, Sage SO. Cyclic nucleotides modulate store-mediated calcium entry through the activation of protein-tyrosine phosphatases and altered actin polymerization in human platelets. J Biol Chem 2001;276: 15666-75

Rosado JA, Redondo PC, Sage SO, Pariente JA, Salido GM. Store-operated $\mathrm{Ca}^{2+}$ entry: vesicle fusion or reversible trafficking and de novo conformational coupling? J Cell Physiol 2005;205:262-9

Rzigalinski BA, Willoughby KA, Hoffman SW, Falck JR, Ellis EF. Calcium influx factor, further evidence it is 5, 6-epoxyeicosatrienoic acid. J Biol Chem 1999;274:175-82

Sargeant P, Farndale RW, Sage SO. The imidazole antimycotics econazole and miconazole reduce agonist- evoked protein-tyrosine phosphorylation and evoke membrane depolarisation in human platelets: cautions for their use in studying $\mathrm{Ca}^{2+}$ signalling pathways. Cell Calcium 1994a; 16:413-8

Sargeant P, Farndale RW, Sage SO. Calcium store depletion in dimethyl BAPTA-loaded human platelets increases protein tyrosine phosphorylation in the absence of a rise in cytosolic calcium. Exp Physiol 1994b;79:269-72

Schilling WP, Rajan L, Strobl-Jager E. Characterization of the bradykinin-stimulated calcium influx pathway of cultured vascular endothelial cells. Saturability, selectivity, and kinetics. J Biol Chem 1989;264:12838-48

Seckl M, Rozengurt E. Tyrphostin inhibits bombesin stimulation of tyrosine phosphorylation, c-fos expression, and DNA synthesis in Swiss 3T3 cells. J Biol Chem 1993;268: 9548-54

Simonson MS, Dunn MJ. $\mathrm{Ca}^{2+}$ signaling by distinct endothelin peptides in glomerular mesangial cells. Exp Cell Res 1991;192:148-56

Sinnett-Smith J, Zachary I, Valverde AM, Rozengurt E. Bombesin stimulation of $\mathrm{p} 125$ focal adhesion kinase tyrosine phosphorylation. Role of protein kinase $\mathrm{C}, \mathrm{Ca}^{2+}$ mobilization, and the actin cytoskeleton. J Biol Chem 1993;268:14261-8

Snider RM, Richelson E. Bradykinin receptor-mediated cyclic GMP formation in a nerve cell population (murine neuroblastoma clone N1E-115). J Neurochem 1984;43:1749-54

Swarup G, Speeg KV Jr, Cohen S, Garbers DL. Phosphotyrosyl-protein phosphatase of TCRC-2 cells. J Biol Chem 1982;257:7298-301

Takemura H, Hughes AR, Thastrup O, Putney JW Jr. Activation of calcium entry by the tumor promoter thapsigargin in parotid acinar cells. Evidence that an intracellular calcium pool and not an inositol phosphate regulates calcium fluxes at the plasma membrane. J Biol Chem 1989;264:12266-71

Taketo M, Yokoyama S, Kimura Y, Higashida H. $\mathrm{Ca}^{2+}$ release and $\mathrm{Ca}^{2+}$ influx in Chinese hamster ovary cells expressing the cloned mouse B2 bradykinin receptor: tyrosine kinase inhibitor-sensitive and- insensitive processes. Biochim Biophys Acta 1997;1355:89-98

Thastrup O, Dawson AP, Scharff O, Foder B, Cullen PJ, Drobak BK, Bjerrum PJ, Christensen SB, Hanley MR. Thapsigargin, a novel molecular probe for studying intracellular calcium release and storage. 1989. Agents Actions 1994;43:187-93

Vostal JG, Jackson WL, Shulman NR. Cytosolic and stored calcium antagonistically control tyrosine phosphorylation of specific platelet proteins. J Biol Chem 1991;266:16911-6

Vostal JG, Fratantoni JC. Econazole inhibits thapsigargin-induced platelet calcium influx by mechanisms other than cytochrome P-450 inhibition. Biochem J 1993;295:525-9

Xu X, Star RA, Tortorici G, Muallem S. Depletion of intracellular $\mathrm{Ca}^{2+}$ stores activates nitric-oxide synthase to generate cGMP and regulate $\mathrm{Ca}^{2+}$ influx. J Biol Chem 1994;269:12645-53

Zachary I, Sinnett-Smith J, Turner CE, Rozengurt E. Bombesin, vasopressin, and endothelin rapidly stimulate tyrosine phosphorylation of the focal adhesion-associated protein paxillin in Swiss 3T3 cells. J Biol Chem 1993; 268:22060-5 